\title{
Spatial and Temporal Patterns of Variation in Environmental Quality of Water and Sediments of Streams in Mined and Unmined Areas with Emphasis on Mercury (Hg) and Arsenic (As)
}

\author{
Stephen T. Annan ${ }^{1}$, Peter 0. Sanful ${ }^{2}$, George Lartey-Young ${ }^{3}$, Rebecca K. Yandam ${ }^{4}$ \\ ${ }^{1}$ Department of Science, SDA College of Education, Asokore Koforidua, Ghana \\ ${ }^{2}$ Department of Fisheries and Water Resources, University of Energy and Natural Resources, \\ Sunyani, Ghana \\ ${ }^{3}$ Department of Environmental Science, University College of Agriculture and Environmental Studies, \\ Bunso, Ghana \\ ${ }^{4}$ Zoomlion Ghana Limited, Jospong Group of Companies, Tamale, Ghana \\ Email: *stwumasiannan@yahoo.com
}

How to cite this paper: Annan, S.T., Sanful, P.O., Lartey-Young, G. and Yandam, R.K. (2018) Spatial and Temporal Patterns of Variation in Environmental Quality of Water and Sediments of Streams in Mined and Unmined Areas with Emphasis on Mercury (Hg) and Arsenic (As). Journal of Geoscience and Environment Protection, 6, 125-140.

https://doi.org/10.4236/gep.2018.69010

Received: July 17, 2018

Accepted: September 10, 2018

Published: September 13, 2018

Copyright (๑) 2018 by authors and Scientific Research Publishing Inc. This work is licensed under the Creative Commons Attribution International License (CC BY 4.0).

http://creativecommons.org/licenses/by/4.0/

(c) (i) Open Access

\begin{abstract}
Heavy metal pollution from both anthropogenic and natural processes can have significant effect on environmental quality of stream and river systems. However, in Ghana, heavy metal pollution of waterbodies is attributed mainly to mining activities but the role of natural mechanisms in altering stream water and sediment quality in relation to heavy metals has received little attention. Spatial and temporal variation in water quality parameters and heavy metal concentrations in water and sediments were studied comparatively in a river and two streams in a gold-rich watershed impacted by heavy mining activities. Samples were collected monthly over a twelve-month period from November 2010 to October 2011 from upstream (unmined) and downstream (mined) sections of the studied streams. Parameters measured include temperature, dissolved oxygen, conductivity, $\mathrm{pH}$, turbidity, colour, mercury $(\mathrm{Hg})$ and arsenic. High spatial variability of water quality parameters was found. $\mathrm{Hg}$ concentrations in water were extremely low in both upstream and downstream areas. Maximum geochemical background levels of $\mathrm{Hg}$ in unmined pristine areas were $2.45 \mathrm{mg} / \mathrm{g}$ whilst arsenic was $29.10 \mathrm{mg} / \mathrm{g}$. By contrast, gold-mined downstream areas recorded $\mathrm{Hg}$ and arsenic concentrations of $8.75 \mathrm{mg} / \mathrm{g}$ and $82.53 \mathrm{mg} / \mathrm{g}$ in stream sediments respectively. Levels of $\mathrm{Hg}$ and arsenic in sediments were several orders of magnitude greater than concentrations in surface water in downstream sections and this may be explained by substances originating from mining activities, upstream transport or re-
\end{abstract}


mobilized sedimented materials in the overlying water column. Our study showed that both natural and human activities may contribute to heavy metal pollution in the highly mineralized watershed of the Pra River Basin. Human factors are however likely to amplify the natural background levels of heavy metals.

\section{Keywords}

Water Quality, Mining, Mercury, Arsenic, Stream Sediments

\section{Introduction}

Heavy metal pollution of aquatic systems from gold mining activities constitutes one of the most pernicious effects on environmental quality. Heavy metal chemical stressors are known to impair metabolic and physiological functions of affected organisms impacting overall ecosystem health [1]. In Ghana, heavy metal contamination of rivers and water ecosystems as a result of small scale mining and artisanal mining operations have been studied extensively [2] [3] [4].

Pollutants such as mercury $(\mathrm{Hg})$ are introduced into the environment through amalgamation processes associated with small scale gold-refining activities [2] [5] [6]. Other contaminants commonly associated with such scale of mining include arsenic, cadmium and lead [7]. These heavy metals are recalcitrant, non-degradable, toxins that have the capacity to bioaccummulate and biomagnify in organisms and foodwebs with potential health risks for humans [8] [9]. For $\mathrm{Hg}$, [10] has indicated the possibility of two main hazards; firstly, occupational inorganic $\mathrm{Hg}$ poisoning by direct inhalation of $\mathrm{Hg}$ vapor during the processes of burning and re-burning $\mathrm{Hg}-\mathrm{Au}$ amalgam. Secondly, a part of $\mathrm{Hg}$ discharged into river systems is methylated and ultimately bioaccummulated to a significant level in fish.

Tropical soils are particularly rich in naturally occurring mercury, arsenic and other heavy metals [11] [12]. Variability in seasonal hydrologic conditions can also influence the transport, transformation and chemical behaviour of heavy metals en route to bottomlands and stream beds where conditions favour biogeochemical Hg methylation and increased toxicity [13] [14]. Hg utilized in the gold extraction process may be incompletely recovered for reuse allowing the residues to escape into the environment [15] [16]. Hg toxicity has therefore become a central issue in environmental management and their presence along with other substances alters the chemistry of aquatic systems imposing acute and chronic stress on aquatic biota [17]. Furthermore, people living along the river and depending on riverine resources have increased health risk from exposure to $\mathrm{Hg}$ and may develop toxic levels through potential repeated consumption of contaminated fish. 
Stream sediments store heavy metal pollutants and can help remobilize stored contaminants into the overlying water column [18]. The stored pollutants commonly bind particulate matter and are transported to new uncontaminated locations [19]. Sediments also archive historical records of pollution and analyses of some palaeorecords indicate that some mining-impacted streams have revealed a geochronological profile of heavy metal pollution in the watershed [20] [21] [22] [23]. Therefore, continuous pollution of streams can occur under both instantaneous activities and sediment recycling [21]. Natural processes such as weathering of source rocks (iron oxides) and subsequent transformations can discharge substantial quantities of heavy metals leading to increased toxicity of water bodies [14] [24]. Arsenic toxicity dynamics occurs across diverse chemical states, as it is able to vary in toxicity and reactivity according to the oxidation state [12]. Arsenic oxidation states are $-\mathrm{III}, 0,+\mathrm{III}$ and $\mathrm{V}$, however its predominant forms are As (III) and As (V) [12].

In Ghana, heavy metal pollution of water and sediments of streams and rivers have mainly been attributed to gold mining activities. In highly mineralized watersheds that are common throughout the country, we expect high background geochemical concentrations of heavy metals in pristine, unmined areas. We also hypothesized that gold-mined areas would have amplified levels of heavy metals above the natural background levels. Our aim therefore was to assess the spatial and temporal variations in the relative concentrations of heavy metals in streams connected to mined and unmined areas within the same watershed. Our research sought to provide information on the relative importance of natural and anthropogenic factors in shaping environmental quality of stream ecosystems.

\section{Materials and Methods}

\subsection{Study Area}

The study was conducted in three flowing water bodies located in the East Akim Municipal Assembly of the Eastern Region of Ghana with a total land area of approximately $725 \mathrm{~km}^{2}$ (Figure 1 ).

The aquatic systems consisted of one large river (Birim) and two relatively small streams, Abohyensuo and Ankobirim which are interconnected within the same drainage network. The Birim River is one of the major tributaries of the Pra River. Sampling locations for the Birim, Abohyensuo and Ankobirim were at Kibi, Apapam and Asikam respectively. The area is located within the rainforest zone of Ghana where mean annual rainfall of $1650 \mathrm{~mm}$ is comparatively higher [25]. The annual climatic cycle is characterized by a major rainfall peak in May/June and a secondary peak in September/October with air temperatures ranging between $21^{\circ} \mathrm{C}$ and $32^{\circ} \mathrm{C}$ [26]. Climatic seasons are marked by hydrological changes resulting from wet and dry periods over the annual cycle. The period of the dry season starts from November and terminates in late March by the annual rains which extend to late October. 

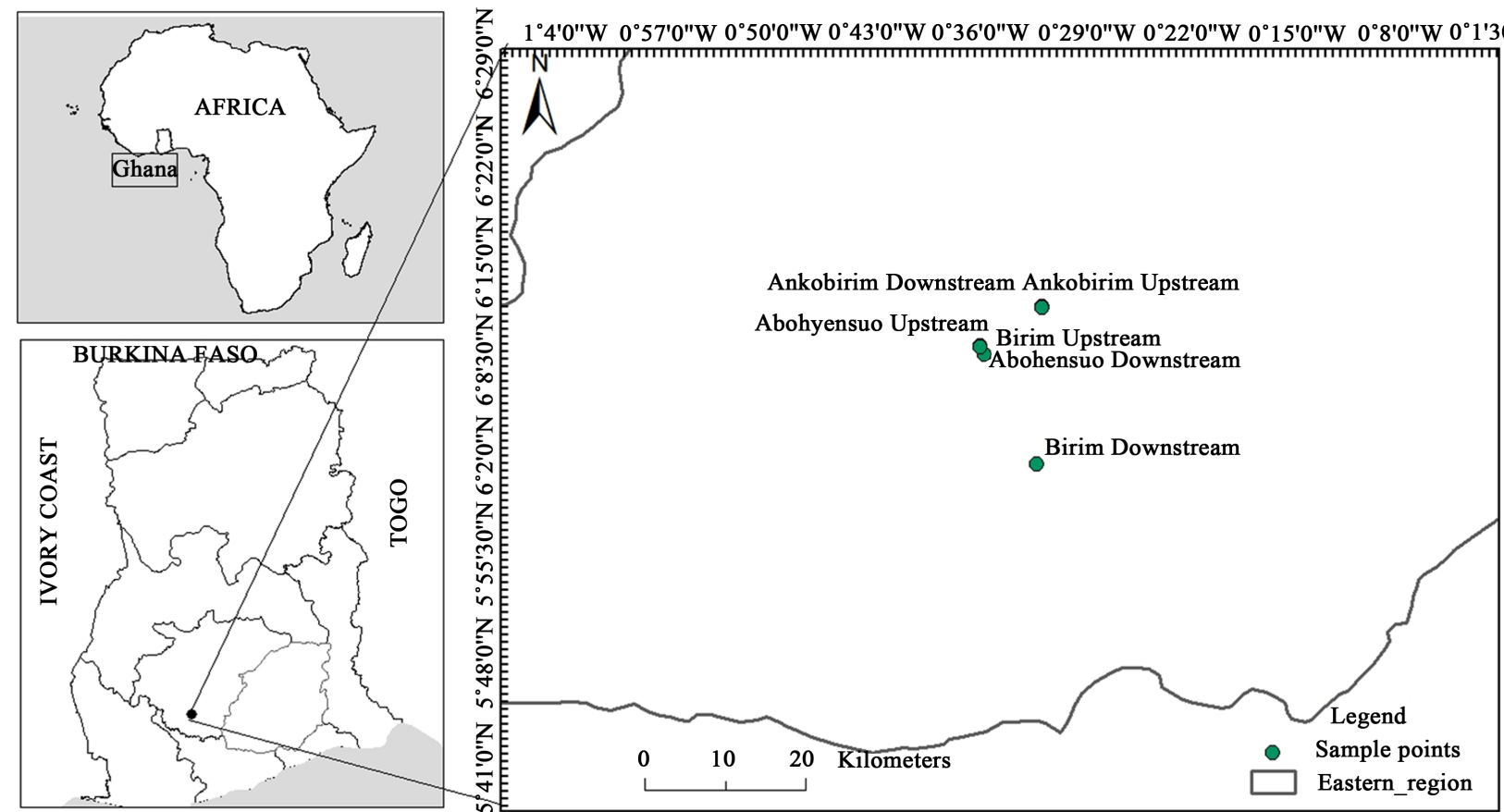

Figure 1. Map of the study area showing sampling locations.

Two sites on each stream corresponding to upstream (unmined) and downstream (mined) conditions were selected. The study locations contain rich gold deposits produced from the underlying Birimian rock formation and constitute some of the most active alluvial gold mining areas in Ghana [27]. Mining activities are commonly carried out along stream banks and within stream channels. Other mineral resources include diamond, bauxite and kaolin [27]. The municipality is drained by many rivers and streams including the Birim, Abohyensuo and Ankobirim which forms part of the Pra River Basin. The watershed also overlaps with the Atewa and Apedwa forest ranges. The drainage network is dendritic flowing in the north-south direction [28]. Field sampling was done from November 2010 to October 2011. Sampling points were marked using a Global Positioning System (GPS) Garmin 60 CSX (Table 1).

\subsection{Sample Collection}

Monthly samples for water quality analysis were collected from upstream and downstream sites of each stream over an annual period from November 2010 to October 2011. Water and sediment samples were collected simultaneously at ten (10) randomly selected sites from each of the upstream and downstream areas of the studied streams located at Kibi, Asikam and Apapam. Stream morphometry namely channel width and water depths were measured in meters. Sampling techniques based on United States Environmental Protection Agency Method 1669 [29] [30] were adopted for sampling in this study. Sampling bottles were pretreated by sterilizing in $10 \%$ nitric acid, rinsed with deionised water and openly dried for 24 hours. Prior to onsite sampling, sample bottles were flushed 
Table 1. GPS location of water and sediment sampling points of studied rivers.

\begin{tabular}{ccc}
\hline Sampling Point & Code & GPS location \\
\hline Birim upstream & BR1 & $06^{\circ} 08^{\prime} 73200^{\circ} 35^{\prime} 892$ \\
Birim downstream & BR2 & $06^{\circ} 10^{\prime} 43200^{\circ} 32^{\prime} 357$ \\
Abohyensuo upstream & AB1 & $06^{\circ} 09^{\prime} 30200^{\circ} 36^{\prime} 154$ \\
Abohyensuo downstream & AB2 & $06^{\circ} 09^{\prime} 27100^{\circ} 36^{\prime} 55$ \\
Ankobirim upstream & AK1 & $06^{\circ} 11^{\prime} 94700^{\circ} 31^{\prime} 998$ \\
Ankobirim downstream & AK2 & $06^{\circ} 11^{\prime} 92300^{\circ} 31^{\prime} 98$ \\
\hline
\end{tabular}

thrice with the stream water to be sampled. The bottles were capped immediately to prevent exposure to air and cross contamination. For temperature, $\mathrm{pH}$, dissolved oxygen (DO) and electrical conductivity (EC), measurements were conducted in situ using water quality multiparameter HORIBA U-51 series. Confirmatory analyses of DO in the various water samples were determined by the Azide modification of the Winkler method [31] [32]. Colour was measured with $\mathrm{HACH}$ DR/2010 portable data logging spectrophotometer. Mercury and arsenic concentrations were measured using the Atomic Absorption Spectrometer [33]. Turbidity was measured with turbidimeter (2100Q Portable Turbidimeter HACH, USA). All field instrumentations were pre-calibrated to standard requirements prior to use. The samples were kept in ice coolers at a temperature of $4^{\circ} \mathrm{C}$ and transported to the laboratory for analysis. Samples were analyzed within 24 hours. Sediment samples were collected using grab samplers. The samples were placed on polythene sheet to prevent contact with other natural ground surface contaminants. All debris were hand-picked and removed from the samples. $5 \mathrm{~g}$ of each sample were collected using a soil scoop and placed in $100 \mathrm{~mm}$ by $140 \mathrm{~mm}$ polythene sample bag and ziplocked. Samples were assigned similar ID's in correspondence to the locations where water samples were collected. The samples were kept in ice cooler to maintain temperature at $4^{\circ} \mathrm{C}$ and transported to laboratory for analysis.

\subsection{Statistical Analysis}

Data were analyzed with SYSTAT 10 (Systat Software Inc.) and statistical differences examined at the $5 \%$ probability level $(p<0.05)$ using one-way Analysis of Variance (ANOVA) to compare variations in monthly means of environmental parameters between water column and sediments at the same site (upstream or downstream) and between water column and sediments at different sites (upstream vrs downstream).

\section{Results}

\subsection{River and Stream Morphometry}

Morphometric features of the streams and river regarding mean width and 
depth are as follows; Abohyensuo $(2.6 \mathrm{~m}$ and $0.53 \mathrm{~m})$, Ankobirim $(1.3 \mathrm{~m}$ and $0.22 \mathrm{~m}$ ) and Birim respectively.

\subsection{Spatial Variation in Water Quality of Rivers}

Mean monthly values of environmental parameters are shown in Table 2. Generally, temperature, $\mathrm{pH}$, dissolved oxygen and $\mathrm{Hg}$ showed restricted range in concentrations among sites. By contrast relatively large differences were observed for the concentration in colour, arsenic and conductivity. Distinct patterns between upstream and downstream water quality conditions were not detected (Table 2).

Only $\mathrm{pH}$ and $\mathrm{DO}$ varied significantly between upstream and downstream sites of the Birim River at $p<0.05$ (Table 3 ) but variation in other streams was not significant. Water quality differences were not significant in Abohyensuo and Ankobirim streams at $p<0.05$ (Table 3). Hg concentrations in stream water were extremely low in all upstream and downstream sites. Arsenic concentrations were higher in upstream than downstream areas in all rivers. General trends of higher upstream concentrations to lower concentrations were apparent in all rivers (Table 2).

Table 2. Monthly mean and standard deviation of stream water quality parameters in upstream and downstream sites. Sample size $(n)=120$.

\begin{tabular}{|c|c|c|c|c|c|c|c|c|}
\hline Site & $\begin{array}{c}\text { Temp. } \\
\left({ }^{\circ} \mathrm{C}\right)\end{array}$ & $\mathrm{pH}$ & $\begin{array}{l}\text { Colour } \\
(\mathrm{HU})\end{array}$ & $\begin{array}{c}\text { Turbidity } \\
\text { (NTU) }\end{array}$ & $\begin{array}{c}\text { Conductivity } \\
(\mu \mathrm{S} / \mathrm{cm})\end{array}$ & $\begin{array}{c}\text { DO } \\
(\mathrm{mg} / \mathrm{L})\end{array}$ & $\begin{array}{c}\text { Mercury } \\
(\mathrm{mg} / \mathrm{L})\end{array}$ & $\begin{array}{c}\text { Arsenic } \\
(\mathrm{mg} / \mathrm{L})\end{array}$ \\
\hline BR1 & $24.3 \pm 0.9$ & $7.62 \pm 0.1$ & $61.4 \pm 60.4$ & $47.6 \pm 31.9$ & $136.8 \pm 12.9$ & $7.6 \pm 1.4$ & $<0.001$ & $0.017 \pm 0.008$ \\
\hline $\mathrm{BR} 2$ & $23.9 \pm 1.3$ & $7.25 \pm 0.2$ & $108.6 \pm 98.8$ & $232.9 \pm 318.3$ & $142.3 \pm 29.3$ & $5.8 \pm 1.6$ & $<0.001$ & $0.008 \pm 0.001$ \\
\hline $\mathrm{AB} 1$ & $25.9 \pm 1.7$ & $7.42 \pm 0.1$ & $25.3 \pm 0.4$ & $6.14 \pm 3.9$ & $143.8 \pm 7.8$ & $6.7 \pm 1.2$ & $<0.001$ & $0.138 \pm 0.226$ \\
\hline $\mathrm{AB} 2$ & $24.9 \pm 1.4$ & $7.58 \pm 0.1$ & $42.7 \pm 25.2$ & $36.4 \pm 24.7$ & $131.3 \pm 9.2$ & $7.5 \pm 0.9$ & $<0.001$ & $0.127 \pm 0.151$ \\
\hline AK1 & $23.9 \pm 1.3$ & $7.03 \pm 0.6$ & $145.8 \pm 236.3$ & $76.3 \pm 130.5$ & $66.9 \pm 16.6$ & $7.5 \pm 0.9$ & $<0.001$ & $0.012 \pm 0.008$ \\
\hline $\mathrm{AK} 2$ & $25.3 \pm 1.1$ & $6.45 \pm 0.5$ & $15.8 \pm 8.6$ & $8.14 \pm 5.80$ & $56.67 \pm 9.9$ & $7.9 \pm 1.8$ & $<0.001$ & $0.065 \pm 0.043$ \\
\hline
\end{tabular}

Table 3. Variation in mean monthly water and sediment quality parameters between upstream and downstream sites at $p<0.05$ significant level and $n=12$. Significant levels indicated with asterisk $\left(^{*}\right)$ Units of measurement for sediment quality is $\mathrm{mg} / \mathrm{g}$.

\begin{tabular}{|c|c|c|c|c|c|c|}
\hline Site & $\mathrm{pH}$ & $\begin{array}{l}\text { Conductivity } \\
(\mu \mathrm{S} / \mathrm{cm})\end{array}$ & $\begin{array}{c}\text { DO } \\
(\mathrm{mg} / \mathrm{L})\end{array}$ & $\begin{array}{l}\text { Turbidity } \\
\text { (NTU) }\end{array}$ & $\begin{array}{c}\text { Mercury } \\
(\mathrm{mg} / \mathrm{L})\end{array}$ & $\begin{array}{c}\text { Arsenic } \\
(\mathrm{mg} / \mathrm{L})\end{array}$ \\
\hline \multicolumn{7}{|l|}{ Water Quality } \\
\hline BR1 vrs BR2 & $0.020^{*}$ & 0.560 & $0.007^{*}$ & 0.295 & 0.638 & 0.225 \\
\hline $\mathrm{AB} 1$ vrs $\mathrm{AB} 2$ & 0.174 & 0.138 & 0.230 & 0.060 & 0.398 & 0.963 \\
\hline AK1 vrs AK2 & 0.504 & 0.340 & 0.670 & 0.384 & 0.504 & 0.179 \\
\hline \multicolumn{7}{|c|}{ Sediment Quality } \\
\hline BR1 vrs BR2 & 0.090 & 0.624 & - & - & 0.060 & 0.709 \\
\hline $\mathrm{AB} 1$ vrs $\mathrm{AB} 2$ & 0.330 & 0.145 & - & - & 0.060 & 0.332 \\
\hline AK1 vrs AK2 & 0.740 & 0.890 & - & - & 0.123 & $0.004^{*}$ \\
\hline
\end{tabular}




\subsection{Spatial Variation in Sediment Quality of Rivers}

For Birim and Ankobirim, mean sediment $\mathrm{pH}$ was higher in downstream sites (Table 5). The range in $\mathrm{pH}$ was low but conductivity was highly variable among rivers. A similar pattern in the spatial variation in conductivity, $\mathrm{Hg}$ and arsenic concentrations were observed (Table 4). The spatial trend in sediment conductivity and $\mathrm{pH}$ were similar to the pattern of changes observed for heavy metals. Higher levels of $\mathrm{Hg}$ and arsenic were recorded in downstream sites of Birim and Ankobirim but the reverse occurred in Abohyensuo where concentrations were higher in upstream sections. Differences in mean $\mathrm{Hg}$ concentration between upstream and downstream sections of Birim and Ankobirim were $81 \%$ and $50 \%$ respectively. Arsenic concentration was highest at downstream of Ankobirim where levels were $82.530 \pm 3.48 \mathrm{mg} / \mathrm{L}$. Highest $\mathrm{Hg}$ concentrations were $8.75 \pm$ $5.53 \mathrm{mg} / \mathrm{L}$ recorded at downstream of Birim. The largest difference in arsenic concentrations were found in Ankobirim where sediment concentrations between upstream and downstream sections differed by $65 \%$. The range in $\mathrm{Hg}$ and arsenic among sites were extremely large with arsenic showing a greater range of variability than $\mathrm{Hg}$ (Table 4). Variation in mean monthly concentrations in arsenic was significant only in Ankobirim at $p<0.05$ (Table 4).

Differences in conductivity between water and sediment layers were only significant at the upstream locations of Birim and Abohyensuo but not Ankobirim (Table 4). Sediment $\mathrm{pH}$ was significant at upstream and downstream locations of Birim (Table 5). Comparison of site-specific heavy metal concentrations

Table 4. Monthly mean and standard deviation of stream sediment quality parameters in upstream and downstream sites. Sample size $(n)=120$.

\begin{tabular}{ccccc}
\hline Site & $\mathrm{pH}$ & $\begin{array}{c}\text { Conductivity } \\
(\mu \mathrm{S} / \mathrm{cm})\end{array}$ & $\begin{array}{c}\text { Mercury } \\
(\mathrm{mg} / \mathrm{g})\end{array}$ & $\begin{array}{c}\text { Arsenic } \\
(\mathrm{mg} / \mathrm{g})\end{array}$ \\
\hline $\mathrm{BR} 1$ & $6.46 \pm 0.17$ & $57.95 \pm 23.84$ & $1.70 \pm 0.82$ & $10.12 \pm 4.34$ \\
$\mathrm{BR} 2$ & $6.82 \pm 0.21$ & $78.67 \pm 61.91$ & $8.75 \pm 5.53$ & $11.51 \pm 4.35$ \\
$\mathrm{AB} 1$ & $6.90 \pm 0.46$ & $53.90 \pm 32.22$ & $2.45 \pm 0.73$ & $11.84 \pm 2.77$ \\
$\mathrm{AB} 2$ & $6.53 \pm 0.59$ & $159.57 \pm 136.55$ & $1.16 \pm 0.32$ & $10.36 \pm 0.42$ \\
$\mathrm{AK} 1$ & $6.18 \pm 0.53$ & $42.48 \pm 15.39$ & $0.78 \pm 0.51$ & $29.10 \pm 10.12$ \\
$\mathrm{AK} 2$ & $6.29 \pm 0.14$ & $41.17 \pm 15.12$ & $1.49 \pm 0.35$ & $82.53 \pm 3.47$ \\
\hline
\end{tabular}

Table 5. Comparison of mean monthly water and sediment quality parameters at upstream and downstream sites at $p<0.05$ significance level. Units for Mercury and Arsenic in water and sediment are $\mathrm{mg} / \mathrm{L}$ and $\mathrm{mg} / \mathrm{g}$ respectively. Sample size $(n)=12$.

\begin{tabular}{ccccc}
\hline Site & $\mathrm{pH}$ & Conductivity $(\mu \mathrm{S} / \mathrm{cm})$ & Mercury & Arsenic \\
\hline BR1 & 0.005 & 0.006 & 0.026 & 0.019 \\
BR2 & 0.029 & 0.191 & 0.050 & 0.013 \\
AB1 & 0.214 & 0.011 & 0.007 & 0.003 \\
AB2 & 0.052 & 0.697 & 0.006 & 0.001 \\
AK1 & 0.117 & 0.134 & 0.050 & 0.010 \\
AK2 & 0.502 & 0.035 & 0.004 & 0.001 \\
\hline
\end{tabular}


between water and sediment compartments of the studied streams showed that $\mathrm{Hg}$ and arsenic had significant variations at all sites at $p<0.05$ with high concentrations recorded in the sediments (Table 5).

\subsection{Seasonal Variation in Mercury and Arsenic Concentrations in Water and Sediments}

Generally, low concentrations of heavy metals were recorded in the dry season and higher concentrations in the wet seasons. Arsenic and mercury were more concentrated in sediments than water columns at all times across the various upstream and downstream areas of all sampled streams and river. Higher seasonal variation of heavy metals in sediments was observed with less fluctuations in water columns (Figure 2 and Figure 3). The temporal patterns and variation in the spatial concentrations of both heavy metals in upstream and downstream areas during dry and wet seasons were remarkably similar (Figure 2 and Figure 3). Arsenic concentrations showed high seasonal variation in water and sediment compartments in upstream and downstream sections (Figure 2). Similar patterns were observed in the spatial and temporal distribution of mercury in mined and unmined sites with elevated concentration of pollutants in sediments at all sites and corresponding lower concentrations in water columns (Figure 3). However downstream sediments were characterized by higher arsenic and mercury concentrations relative to upstream areas and overlying water columns. Concentrations of both heavy metals were more diluted in both water and sediment environments during the dry season which extended from November to March. Peak concentrations of arsenic and mercury in water and sediments were found in the wet seasons from April to June and secondary peak during the minor rainy season from September to October. The highest concentration of arsenic was recorded downstream at AK2.

\section{Discussion}

Data obtained from the study showed reduced spatial and temporal variability in water quality parameters namely temperature, dissolved oxygen, conductivity, turbidity and $\mathrm{pH}$ at all sites sampled, which indicates a uniform physicochemical environment least affected by seasonal changes in stream hydrology. By contrast, there were clear spatial patterns and variation in the distribution of $\mathrm{Hg}$ and arsenic in mined and unmined areas. Heavy metals in rivers originate from multiple sources such as geological weathering, industrial effluents and domestic effluents [34]. Risk to rivers due to large contamination from mining operations and activities potentially vary considerably in different reaches as toxicant or chemical pollutants depending on their properties are progressively broken down, changed from one state to the other or immobilized after discharge into a river [35].

$\mathrm{Hg}$ concentrations in water was low in both upstream and downstream areas in comparison with Ghana EPA standard limit of $0.1 \mathrm{ppb}$ and WHO 0.001 [3]. 


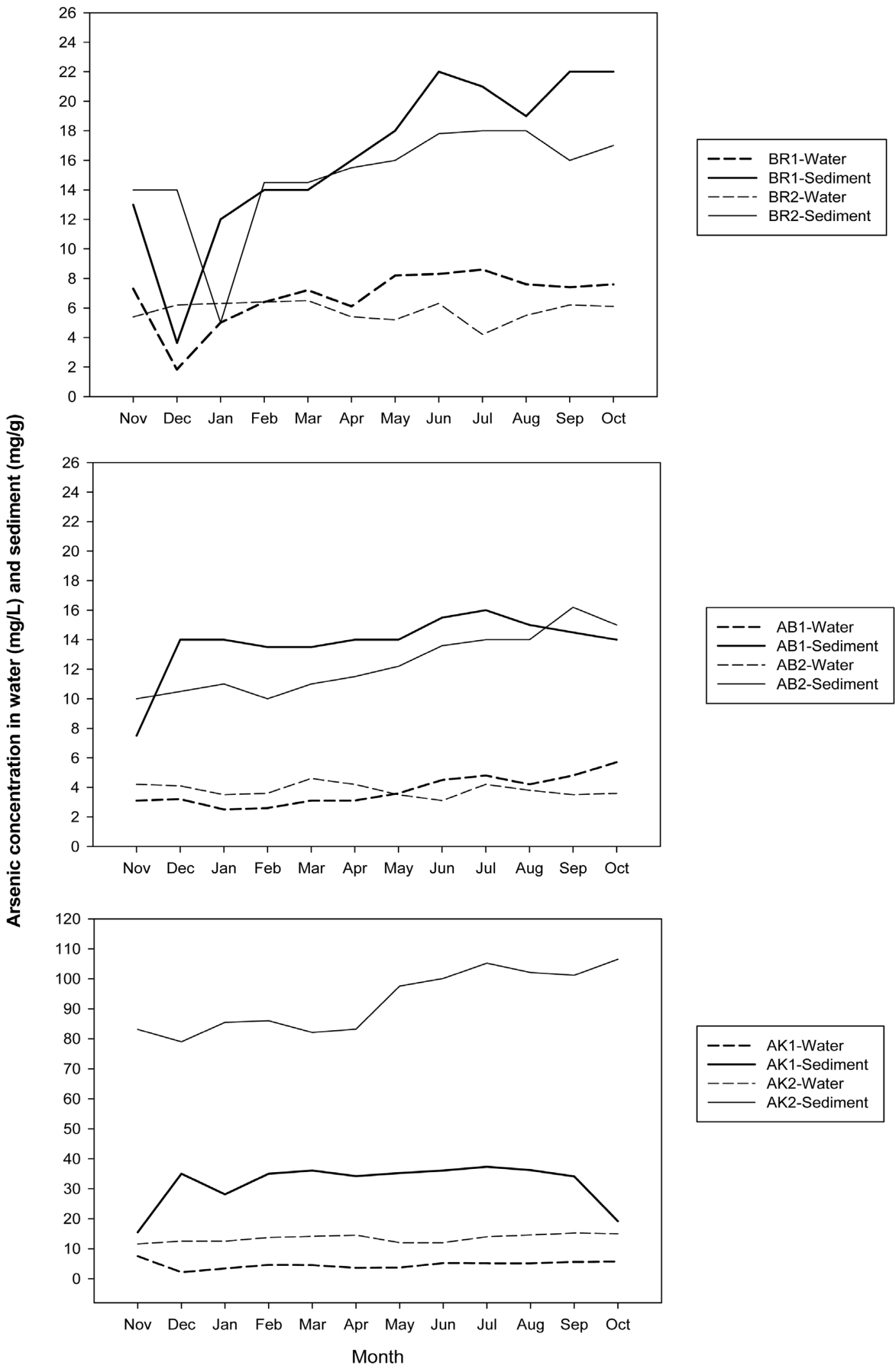

Figure 2. Seasonal variation in arsenic concentrations in water and sediments of upstream (unmined) and downstream (mined) stream and river sections. 


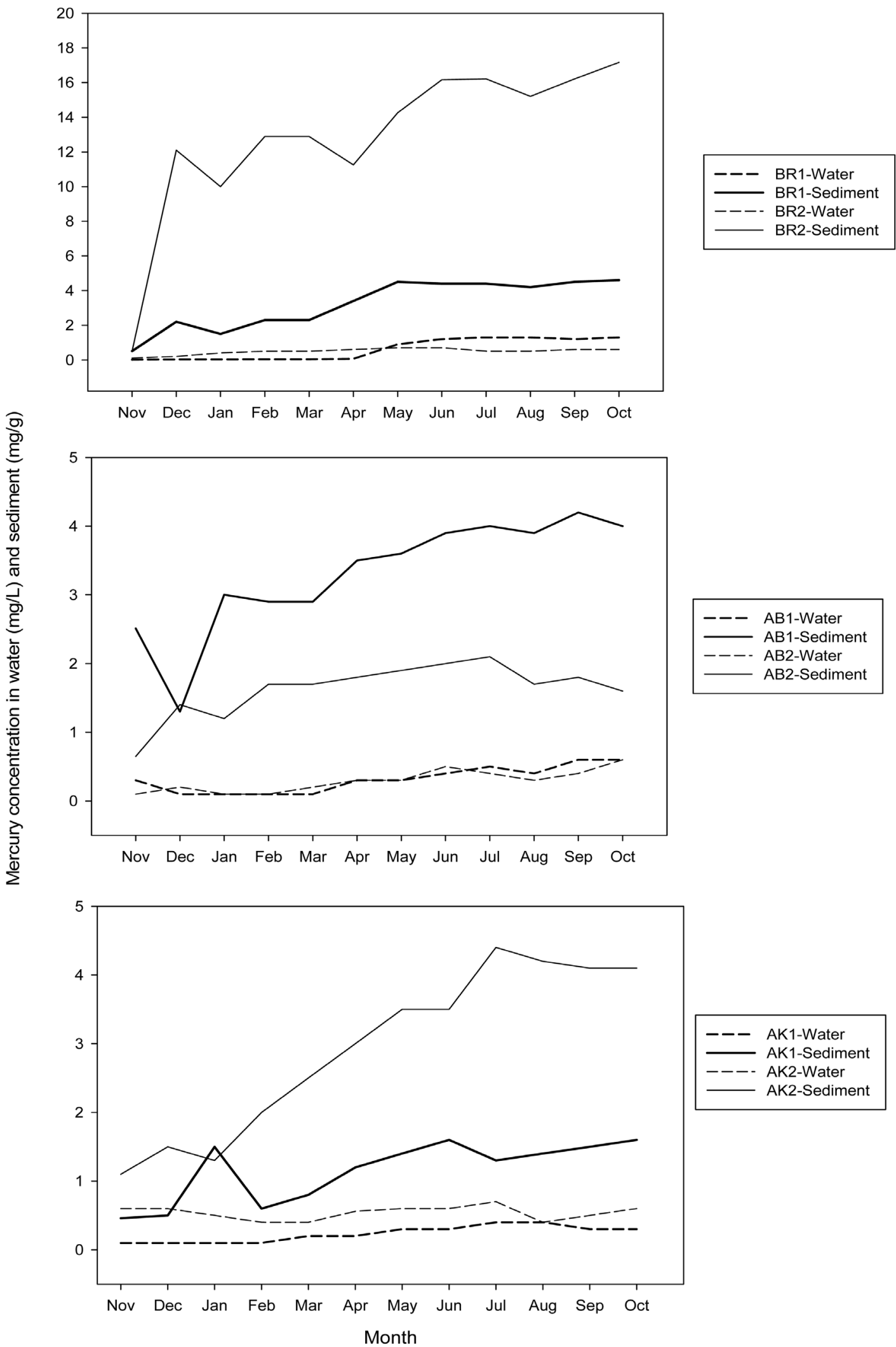

Figure 3. Seasonal variation in mercury concentrations in water and sediments of upstream (unmined) and downstream (mined) stream and river sections. 
This could possibly be due to the high flushing rates of the rivers from the high precipitation experienced in the tropical rainforest zone. Low $\mathrm{Hg}$ levels might also be attributed to higher ingestion rate of organisms, resuspension of sediments and absorption onto particulates as monitoring periods coinciding with the onset of the dry season can account for reduced transport and suspension from hydrological influences. According to [36], $\mathrm{Hg}$ dispersion is generally low under conditions of limited river discharge which can affect its transportation in large elemental, metallic form from upstream to downstream areas. Sampling distances may also contribute to reductions in $\mathrm{Hg}$ levels as noted by [37]. Iron oxide rich laterites and swamps also act as natural barriers for the dispersion of $\mathrm{Hg}$ in rivers [37]. Risk to rivers due to large contamination from mining operations and activities potentially vary considerably in different reaches as toxicant or chemical pollutants depending on their properties are progressively broken down, changed from one state to the other or immobilized after discharge into a river [35].

Arsenic concentrations were relatively high in upstream areas that were not associated with mining activities in comparison to USEPA reference limit for soil $0.4 \mu \mathrm{g} / \mathrm{g}$. This suggests that arsenic may be released into surface waters by natural processes of erosion, dissolution and weathering of rocks which do contribute significantly to heavy metal contamination of environmental systems [14] [24]. Pedogensis can also explain the high levels of Arsenic observed [38]. Sediment $\mathrm{pH}$ measured in this study indicated a lower 6.18 to a maximum 6.90 indicating a high acidic state of soils in the study area which can increase arsenic content by increasing mobilization and availability [39] [40]. Arsenic tends to concentrate in the surface horizons because of atmospheric deposition, vegetation recycling, and the presence of oxides and organic matter which reduce mobility [41]. According to [42], arsenic may be found in water which has flowed through arsenic-rich rocks. The presence of arsenic may impact significantly on aquatic life. Environments contaminated with arsenic may affect aquatic biodiversity by limiting species abundance and diversity [27]. Naturally, arsenic exhibits fairly complex chemistry and can be present in several oxidation states (-III, 0, III, V) [43] which can increase its persistence in the environment. As noted by [44] and observed in this study, the high concentrations of arsenic in unmined areas suggest that heavy metal contamination from natural processes may be substantial in the gold-rich geology of the area.

Arsenic concentration was much lower in downstream of rivers in comparison to WHO reference limit of $10 \mu \mathrm{g} / \mathrm{g}$ ([45]; Table 6) despite high mining activity. The low levels of arsenic in downstream areas of river water column suggest physical processes may lead to rapid sedimentation and storage in the river sediments. The sediments may thus act as a reservoir that may later remobilize arsenic and increase concentrations in the water column. The differential concentrations of arsenic in water and sediment may create a potential for contamination in the overlying water column when no mining activity has occurred. 
Table 6. Summary guideline values for mercury (Hg) and arsenic (As).

\begin{tabular}{ccc}
\hline Medium & Mercury (Hg) & Arsenic (As) \\
\hline Soil & $0.0001 \mathrm{mg} / \mathrm{g} \mathrm{THg}$ (US EPA, 2011 \& Buchman, 2008) & $0.0004 \mathrm{mg} / \mathrm{g}$ (USEPA, 2011) \\
Plant & $0.0005 \mathrm{mg} / \mathrm{g} \mathrm{MeHg}$ (FAO, 2013/WHO) & $0.0001 \mathrm{mg} / \mathrm{g}$ (FAO, 2013) \\
Sediment & $0.00018 \mathrm{mg} / \mathrm{g} \mathrm{THg}$ (USEPA, 2006) & $0.0098 \mathrm{mg} / \mathrm{g}$ (USEPA, 2006) \\
Water & $0.006 \mathrm{mg} / \mathrm{L} \mathrm{Inorg.} \mathrm{Hg} \mathrm{(WHO,} \mathrm{2011)}$ & $0.0010 \mathrm{mg} / \mathrm{g}$ (WHO, 2011) \\
& $0.0003 \mathrm{mg} / \mathrm{g} \mathrm{MeHg}$ (USEPA, 2011) & \\
Fish & $0.0005 \mathrm{mg} / \mathrm{g} \mathrm{MeHg}$ (FAO, 2013) & \\
Tailings & $0.0001 \mathrm{mg} / \mathrm{g} \mathrm{THg}$ (US EPA, 2011 \& Buchman, 2008)
\end{tabular}

Source: [8].

This sediment accumulation of arsenic may be toxic to plant and animal life and consequently affect aquatic health particularly sediment-dwelling organisms. The presence of arsenic may be detrimental to aquatic organisms as they lead to inhibition of several functional physiological and biochemical activities [9].

Sediment concentrations of $\mathrm{Hg}$ were several orders of magnitude higher than in the overlying river water column. Downstream sediments however had higher concentrations than upstream areas. The generally high sediment concentrations may be due to mining activities in downstream sections amplified by natural background concentrations of $\mathrm{Hg}$ in lithogenic soils. Natural lithogenic Hg has been found in very high concentrations in areas which have not been exposed to mining [7] [43], suggesting that the sediments in the studied rivers may have high natural geochemical background levels of $\mathrm{Hg}$. These may be elevated by downstream mining activities that contribute significant quantities into waterbodies and may be stored in the sediment in relatively high concentrations. The increases in $\mathrm{Hg}$ concentrations in downstream sediments relative to upstream zones have been found to be determined principally by mining activities [11]. The maximum geological background concentrations of $\mathrm{Hg}$ and arsenic in upstream pristine areas are comparable to levels in non-gold mined streams reported by [11].

The research showed strong evidence for elevated concentrations of mercury and arsenic in sediments coinciding with seasonal maximum rainfall periods which is potentially responsible for increased transmission and deposition of heavy metals with increased stream discharge. The findings are further evidence for the important role that the hydrological seasonality of tropical streams play in the spatial distribution of heavy metals in highly mineralized watersheds exposed to the intensity of seasonal rainfall. High metal concentrations in streams have been found in periods of increased precipitation and stream discharge accelerating the delivery of heavy metals to downstream sediments through adsorption to soil particulates and their suspension in water [3] [12]. The high storage capacity of sediments for heavy metals can also lead to subsequent remobilization into stream water during periods when transmission and deposi- 
tion has been drastically curtailed by low stream flows immediately following the rainy season [20]. On the contrary, significant reductions off heavy metals in sediments have been associated with dry seasons without the noted hydrological influences on stream discharge that increase mobility of chemicals in water and sediments [1].

\section{Conclusion}

In conclusion, there was high spatial and temporal variation in heavy metal concentrations and environmental quality of the river and streams. Sediments had higher concentrations of $\mathrm{Hg}$ and As than surface water because of their high adsorptive and storage capacity. Surface water concentrations were low because of the rapid flushing rate. Natural contamination of water bodies with heavy metals may be apparent because of the highly rich mineral deposits and the high rainfall available to facilitate weathering, dissolution, transmission and sedimentation of heavy metals in the sediment. Natural and anthropogenic factors may play a role in pollution processes but evidence indicates that natural factors may play an equally important role.

\section{Acknowledgements}

We wish to thank the workers at Water Research Institute-CSIR, Accra and Ecological Laboratory, University of Ghana, Legon for their assistance in the laboratory analyses. Our thanks also go to Mr. Emmanuel Ansah of (VBRP) University of Ghana, Legon for his selfless assistance to the success of this work.

\section{Conflicts of Interest}

The authors declare no conflicts of interest regarding the publication of this paper.

\section{References}

[1] Nwadinigwe, C.A., Udo, G.J. and Nwadinigwe, A.O. (2014) Seasonal Variations of Heavy Metals Concentrations in Sediment Samples around Major Tributaries in Ibeno Coastal Area, Niger Delta, Nigeria. International Journal of Scientific \& Technology Research, 3, 254-265.

[2] Nartey, V.K., Klake, R.K., Doamekpor, L.K. and Sarpong-Kumankomah, S. (2012) Speciation of Mercury in Mine Waste: Case Study of Abandoned and Active Goldmine Sites at the Bibiani-Anwiaso-Bekwai Area of South Western Ghana. Environmental Monitoring and Assessment, 184, 7623-7634. https://doi.org/10.1007/s10661-012-2523-2

[3] Armah, F.A., Obiri, S., Yawson, D.O., Pappoe, A.N.M. and Akoto, B. (2010) Mining and Heavy Metal Pollution: Assessment of Aquatic Environments in Tarkwa (Ghana) Using Multivariate Statistical Analysis. Journal of Environmental Statistics, 1, $1-13$.

[4] Kpan, J.D.A., Boadu, K.O. and Anukwah, G. (2014) Heavy Metal Pollution in Soil and Water in Some Selected Towns in Dunkwa-on-Offin District in the Central Re- 
gion of Ghana as a Result of Small Scale Gold Mining. Journal of Agricultural Chemistry and Environment, 3, 40-47.

[5] Armah, F.A., Obiri, S., Yawson, D.O., Onumah, E.E., Yengoh, G.T., Afrifa, E.K.A. and Odoi, J.O. (2010) Anthropogenic Sources and Environmentally Relevant Concentrations of Heavy Metals in Surface Water of a Mining District in Ghana: A Multivariate Statistical Approach. Journal of Environmental Science and Health, Part A, 45, 1804-1813. https://doi.org/10.1080/10934529.2010.513296

[6] Antwi-Agyei, P., Hogarh, J.N. and Foli, G. (2009) Trace Elements Contamination of Soils around Gold Mine Tailings Dams at Obuasi, Ghana. African Journal of Environmental Science and Technology, 3, 353-359.

[7] Fadini, P.S. and Jardim, W.F. (2001) Is the Negro River Basin (Amazon) Impacted by Naturally Occurring Mercury? Science of the Total Environment, 275, 71-82. https://doi.org/10.1016/S0048-9697(00)00855-X

[8] Quenel, P., Saviuc, P. and Godard, E. (2007) Le mercure en Guyane: Risque sanitaire et enjeux de santé publique. Bulletin d'Alerte et de Surveillance Antilles Guyane [BASAG], No. 7. 16 p.

[9] Oppong Afum, B. and Owusu, C.K. (2016) Heavy Metal Pollution in the Birim River of Ghana. International Journal of Environmental Monitoring and Analysis, 4, 65-74. https://doi.org/10.11648/j.ijema.20160403.11

[10] Akagi, H., Mal, O., Branches, F.J.P., Kinjo, Y., Kashima, Y., Guimaraes, J.R.D., Oliveira, R.B., Haraguich, K., Pfeiffer, W.C., Takizawa, Y. and Kato, H. (1995) Human Exposure to Mercury Due to Goldmining in the Tapajos River Basin, Amazon, Brazil: Speciation of Mercury in Human Hair, Blood and Urine. Water, Air, and Soil Pollution, 80, 85-94. https://doi.org/10.1007/BF01189656

[11] Laperche, V., Hellal, J., Maury-Brachet, R., Joseph, B., Laporte, P., Breeze, D. and Blanchard, F. (2014) Regional Distribution of Mercury in Sediments of the Main Rivers of French Guiana (Amazonian Basin). SpringerPlus, 3, 322. https://doi.org/10.1186/2193-1801-3-322

[12] Toujaguez, R., Onob, F.B., Martins, V., Cabrera, P.P., Blanco, A.V., Bundschuh, J. and Guilherme, L.R.G. (2013) Arsenic Bioaccessibility in Gold Mine Tailings of Delita, Cuba. Journal of Hazardous Materials, 262, 1004-1013. https://doi.org/10.1016/j.jhazmat.2013.01.045

[13] Morel, F.M.M., Kraepiel, A.M.L and Amyot, M. (1998) The Chemical Cycle and Bioaccumulation of Mercury. Annual Review of Ecology and Systematics, 29, 543-566. https://doi.org/10.1146/annurev.ecolsys.29.1.543

[14] Kelepertzis, E., Argyraki, A., Daftsi, E.I. and Ballas, D. (2010) Geochemical Background Heavy Metal Concentrations of Stream Sediments at Mineralized Areas of NE Chalkidiki. Hellenic Journal of Geosciences, 45, 152-162.

[15] Pfeiffer, W.C. and Larceda, L.D. (1988) Mercury Input into the Amazon Region, Brazil. Environmental Technology Letters, 9, 325-330. https://doi.org/10.1080/09593338809384573

[16] Meech, J.A., Veiga, M.M. and Troman, D. (1995) Reactivity of Mercury from Gold Mining Activities in Darkwater Ecosystems. AMBIO, 27, 92-98.

[17] Boening, D.W. (2000) Ecological Effects, Transport, and Fate of Mercury: A General Review. Chemosphere, 40, 1335-1351. https://doi.org/10.1016/S0045-6535(99)00283-0

[18] Audry, S., Schäfer, J., Blanc, G. and Jouanneau, J.M. (2004) Fifty-Year Sedimentary record of Heavy Metal Pollution $(\mathrm{Cd}, \mathrm{Zn}, \mathrm{Cu}, \mathrm{Pb})$ in the Lot River Reservoirs 
(France). Environmental Pollution, 132, 413-426.

https://doi.org/10.1016/j.envpol.2004.05.025

[19] Ullrich, S.M., Tanton, T.W. and Abdrashitova, S.A. (2001) Mercury in the Aquatic Environment: A Review of Factors Affecting Methylation. Critical Reviews in Environmental Science and Technology, 31, 241-293. https://doi.org/10.1080/20016491089226

[20] Bhuyan, M.S. and Bakar, M.A. (2017) Seasonal Variation of Heavy Metals in Water and Sediments in the Halda River, Chittagong, Bangladesh. Environmental Science and Pollution Research, 24, 27587-27600. https://doi.org/10.1007/s11356-017-0204-y

[21] Masunaga, S., Yao, Y., Ogura, I., Nakai, S., Kanai, Y., Yamamuro, M. and Nakanishi, J. (1999) Historical Contribution of Different Sources to Environmental Dioxin pollution Estimated from the Lake Shinji Sediment Core. Organohalogen Compound, 43, 383-386.

[22] Begum, A., Ramaiah, M., Khan, H.I. and Veena, K. (2009) Heavy Metal Pollution and Chemical Profile of Cauvery River Water. E-Journal of Chemistry, 6, 47-52. https://doi.org/10.1155/2009/154610

[23] Hogarh, J.N., Adu-Gyamfi, E., Nukpezah, D., Akoto, O. and Adu-Kumi, S. (2016) Contamination from Mercury and Other Heavy Metals in a Mining District in Ghana: Discerning Recent Trends from Sediment Core Analysis. Environmental Systems Research, 5, 15. https://doi.org/10.1186/s40068-016-0067-0

[24] Kelepertzis, E., Argyraki, A. and Daftsis, E. (2012) Geochemical Signature of Surface Water and Stream Sediments of a Mineralized Drainage Basin at NE Chalkidiki, Greece: A Pre-Mining Survey. Journal of Geochemical Exploration, 114, 70-81. https://doi.org/10.1016/j.gexplo.2011.12.006

[25] Ayibotele, N.B. and Tuffour-Darko, T. (1979) Sediment loads in the Southern Rivers of Ghana. Water Resources Research Unit-CSIR.

[26] Ankomah, Y.O. (1986) Annual Streamflow Characteristics of Major Ghanaian Rivers. WRRI.

[27] East Akim Municipal Assembly (2010) Technical Report for the District.

[28] Burton, G.A. (1991) Assessing the Toxicity of Freshwater Sediments. Environmental Toxicology and Chemistry, 10, 1585-1627. https://doi.org/10.1002/etc.5620101204

[29] United States, Environmental Protection Agency, Office of Science and Technology, Engineering and Analysis Division (1996) Method 1669 Sampling Ambient Water for Trace Metals at EPA Water Quality Criteria Levels. United States, Environmental Protection Agency, Office of Water, Engineering and Analysis Division, Washington DC.

[30] Joy, J. (2006) Standard Operating Procedure (SOP) for Manually Obtaining Surface Water Samples, Version 1.0. SOP Number EAP015, Washington State Department of Ecology, Olympia, WA.

[31] American Public Health Association (APHA) (1998) Standard Methods for the Examination of Water and Wastewater. 20th Edition, Washington DC, USA, 4-146.

[32] Walkley, A. and Black, L. (1984) Examination of Dejtjareff Method for Determining Soil Organic Matter and a Proposal Modification of the Chromic Acid Titration Method. Soil Science Society, 57, 29-38.

[33] American Public Health Association (APHA) (1995) Standard Methods for the Examination of Water and Wastewater. 19th Edition, American Public Health Association, American Water Works Association and Environment Federation 
Washington DC, USA, 4-91.

[34] Alloway, B.J. (2012) Heavy Metals in Soils: Trace Metals and Metalloids in Soils and Their Bioavailability. 3rd Edition, Springer, Heidelberg, 697.

[35] Smolders, A.J.P., Tomassen, H.B.M., Lamers, L.P.M., Lomans, B.P. and Roelofs, J.G.M. (2002) Peat Bog Restoration by Floating Raft Formation: The Effects of Groundwater and Peat Quality. Journal of Applied Ecology, 39, 391-401. https://doi.org/10.1046/j.1365-2664.2002.00724.x

[36] Straaten, P.V. (2000) Mercury Contamination Associated with Small-Scale Gold Mining in Tanzania and Zimbabwe. Science of the Total Environment, 259, 105-113. https://doi.org/10.1016/S0048-9697(00)00553-2

[37] Horvat, M., Nolde, N., Fajon, V., Jereb, C., Logar, M., Lojen, S., Jacimovic, R., Falnoga, I., Liya, Q., Faganeli, J. and Drobne, D. (2003) Total Mercury, Methylmercury and Selenium in Mercy Polluted Areas in the Province Guizhou, China. Science of the Total Environment, 304, 231-256. https://doi.org/10.1016/S0048-9697(02)00572-7

[38] Huanxin, W. and Xiang, L. (1997) Geochemical Migration of Arsenic and Its Environmental Effect. Journal of Environmental Sciences, 9, 162-171.

[39] Kabata-Pendias, A. (2011) Trace Elements in Soils and Plants. 4th Edition, CRC, Boca Raton.

[40] Da Sacco, L., Baldassarre, A. and Masotti, A. (2012) Diet's Role in the Toxicity of Inorganic Arsenic (iAs): A Journey from Soil to Children's Mouth. Journal of Geochemical Exploration, 131, 45-51. https://doi.org/10.1016/j.gexplo.2012.11.014

[41] Wuana, R.A. and Okieimen, F.E. (2011) Heavy Metals in Contaminated Soils: A Review of Sources, Chemistry, Risks and Best Available Strategies for Remediation. ISRN Ecology, Article ID: 402647.

[42] WHO (2000) Arsenic in Drinking Water. WHO Fact Sheet No. 210.

[43] Lechler, P.J., Miller, J.R., Lacerda, L.D., Vinson, D., Bonzongo, J.C., Lyons, W.B. and Warwick, J.J. (2000) Elevated Mercury Concentrations in Soils, Sediments, Water, and Fish of the Madeira River Basin, Brazilian Amazon: A Function of Natural Enrichments. Science of the Total Environment, 260, 87-96. https://doi.org/10.1016/S0048-9697(00)00543-X

[44] Ako, T.A., Onoduku, U.S., Oke, S.A., Adamu, I.A., Ali, S.E., Mamodu, A. and Ibrahim, A.T. (2014) Environmental Impact of Artisanal Gold Mining in Luku, Minna, Niger State, North Central Nigeria. Journal of Geosciences and Geomatics, 2, 28-37.

[45] WHO (2011) Guidelines for Drinking-Water Quality. WHO/SDE/WSH/03.04/71/rev1. 